\title{
CYTOPLASMiC AND NUCLEAR MATURATION OF OOCYTES IN MAMMALS - LIVING IN THE SHADOW OF CELLS DEVELOPMENTAL CAPABILITY
}

\author{
Marta Rybska ${ }^{*}$, Sandra Knap ${ }^{2,3}$, Maurycy Jankowski ${ }^{3}$, Michal Jeseta ${ }^{4}$, Dorota Bukowska ${ }^{5}$, Paweł \\ Antosik $^{5}$, Michał Nowicki², Maciej Zabel ${ }^{2,6}$, Bartosz Kempisty ${ }^{2,3,4}$, Jędrzej M. Jaśkowski ${ }^{5}$
}

\begin{abstract}
The pig is a polyestrous animal in which the ovarian cycle lasts about 21 days and results in ovulation of 10-25 oocytes. Ovum reaches $120-150 \mu \mathrm{m}$ in diameter, with the surrounding corona radiata providing communication with the environment. The zona pellucida is composed of glycoproteins: ZP1, ZP2, ZP3. In the course of oogenesis, RNA and protein accumulation for embryonic development occurs. Maternal mRNA is the template for protein production. Nuclear, cytoplasmic and genomic maturity condition the ability of the ovum to undergo fertilization. There are several differences in protein expression profiles observed between in vitro and in vivo conditions. Oogenesis is the process of differentiating female primary sex cells into gametes. During development gonocytes migrate from the yolk sac into the primary gonads with TGF-1, fibronectin, and laminin regulating this process. Cell cycle is blocked in dictyotene. Primary oocyte maturation is resumed before each ovulation and lasts until the next block in metaphase II. At the moment of penetration of the sperm into the ovum, the metaphase block is broken. The oocytes, surrounded by a single layer of granular cells, form the ovarian follicle. The exchange of signals between the oocyte and the cumulus cells done by gap-junctions, as well as various endo and paracrine signals. The contact between the corona radiata cells provides substances necessary for growth, through the same gap junctions. Studies on follicular cells can be used to amplify the knowledge of gene expression in these cells, in order to open way for potential clinical applications.
\end{abstract}

Running title: ovarian cysts formation

Keywords: mammals, folliculogenesis, ovarian pathophysiology

\footnotetext{
${ }^{1}$ Departemnt of Preclinical Sciences and Infectious Diseases, Poznan University of Life Sciences, Poznan, Poland

${ }^{2}$ Department of Histology and Embryology, Poznan University of Medical Sciences, Poznan, Poland

${ }^{3}$ Department of Anatomy, Poznan University of Medical Sciences, Poznan, Poland

${ }^{4}$ Department of Obstetrics and Gynecology, University Hospital and Masaryk University, Czech Republic

${ }^{5}$ Veterinary Center, Nicolaus Copernicus University in Toruń, Torun, Poland

${ }^{6}$ Department of Histology and Embryology, Wroclaw Medical University, Wroclaw, Poland

* Correspondence: rybska@up.poznan.pl

Full list of author information is available at the end of article 


\section{Morphology of oocyte in mammals}

Domestic swine is one of the polyestrous animals, females, mature sexually, manifest heat symptoms and ability to reproduce throughout the year. The estrous cycle lasts for about 21 days, the appropriate heat phase covers an average of 2-3 days, and ovulation occurs about 43 hours after the start of heat. During one cycle, pigs ovulate between 10 and 25 ova. The ovarian follicles, at the time of ovulation, reach a diameter of about $0.5-1 \mathrm{~cm}$. Oocytes, after leaving the follicle, direct to the ampule of the fallopian tube in which they are fertilized. After the formation of zygote, the dividing embryo is transported by the fallopian tube to the uterus in which the implantation occurs [1].

Ovum cell belongs to the oldest and largest cells of the organism. In breeding animals the diameter is from 120 to $150 \mu \mathrm{m}$. It is filled with reserve substances, which are the basis for proper embryo development in the first days of its life. The female gamete is surrounded with corona radiata, which is responsible for maintaining the communication between the oocyte and the somatic cells. The cytoplasm of an egg is protected by a zona pellucida, composed of three glycoproteins ZP1, ZP2, ZP3. The organelles consist of: Golgi apparatus, mitochondria, microvilli, endoplasmic reticulum, core and nucleus [2]. The homogeneity of the oocyte, its color, the degree of degeneration and the number of layers of corona radiata cells, are the morphological criteria for the fitness of the cell to IVM (in vitro maturation) [3], [4].

\section{Cytoplasmic maturation of oocytes}

The process of oogenesis is most intensive in the diplotene phase when it comes to collecting the synthesized RNAs and proteins necessary for the future development of the embryo. Maternal mRNA produced during early stages of oogenesis is also a matrix for a pool of proteins that are expressed at an early stage of embryonic development. Oocytes belong to a group of highly specialized cells. Their differentiation affects the production of both, the organelles that are common to all eukaryotic cells and the ones specific to oocytes only. Oocyte cell division is governed by specific mechanisms of gene expression regulation [5]-[9].

The primary factor determining the ability to fertilize an egg, the proper development of the embryo and then the fetus is its maturity. Oocytes with the highest competence reach nuclear, cytoplasmic and genomic maturity. The cytoplasmic maturity of the oocyte is influenced by the development of molecular and structural maturity, which in subsequent stages determines proper fertilization and mitotic division of the embryo. Three main processes are distinguished in cytoplasmic maturation, including organelle movement, cytoskeleton reorganization and molecular maturation [10]. Different types of medium are supplemented by the addition of fetal calf serum (FCS), follicular fluid (FF) and other supplements in the form of gonadotropin hormones and growth factors are factors that enable maturity [11]. However, the oocytes obtained by culturing in vitro may not possess full growth potential, resulting in abnormal development of the embryo, which would then generate defects in the developing fetus. Cell culture may lead to disorders in epigenetic gene modification, protein synthesis, abnormal transport of signals, ions, which, in turn, lead to disorders in the maturation of ooplasm [7], [12]-[15].

The most competent for fertilization IVF (in vitro fertilization) is the oocyte derived from large, preovulatory ovarian follicles. Cells derived from antral follicles exhibit limited developmental capacity, which often prevents them from attaining MII stage [12], [16]. However, in many animal species, the high incidence of embryos that achieve the blastocyst stage through in vitro cultures remains low (about $40 \%$ in cattle and about $20 \%$ in pigs) [16], [17]. In the growth phase, the oocyte synthesizes stores and maternal mRNA and protein, which are necessary for the proper development of the early embryonic stages. Oocyte reserve material, plays an important role in the critical moments of embryo development such as the activation of the embryonic genome (8-16 cell stage), and the transition from the morula stage to the blastocyst during which early embryo mortality may occur [7]. In vitro, it has been shown, that the glycoprotein contained in the zona pellucida (ZP1, ZP2, ZP3 and ZP4) with ITGB (integrins) are the main factor which affects the fertilization of pig oocytes in vitro [18], [19].

Budna et al., using microarray analysis and RTqPCR, compared immature porcine oocytes in the GV stage with mature oocytes at the MII stage. The study showed upregulation of genes affecting oocyte morphology, adhesion, cellular migration and intracellular communication, accompanied by down regulation of genes that are related to the regulation of adhesion, proliferation and migration, reorganization of microtubules and cell differentiation processes in oocytes. In porcine oocytes, the vast majority of genes recruited in morphogenesis can affect cell maturation as compared to mature oocytes. This means, that during morphogenesis, the process of oocyte maturation and developmental capacity are regulated by cellular modifications [20].

Comparative analysis of in vivo and in vitro maturated oocytes showed significant differences in the number and quality of proteins involved in cell cycle regulation and ensuring the normal development of the embryo and fetus. Human oocytes that were matured in laboratory conditions, were proven to lack 9 protein that are otherwise present in in vivo matured oocytes [21]. The same tendency, with a much lower levels of protein expression in in vitro maturation as compared to in vivo, was shown in studies concerning cattle oocytes [21]. 
In mammals intense protein synthesis in oocytes occurs before the resumption of the maturation process. In goats, pigs, cows and sheep, cells do not undergo meiosis in the presence of protein synthesis inhibitors. The transcription process completely stops during meiotic maturation, with gene expression regulated only at the translation level. This process is regulated by phosphorylation of eukaryotic initiation factors (eIFs) and their regulators [22], [23]. It has been demonstrated that the cells in GV stage (Germinal vesicle stage) have a low level of translation, while cells in GVBD stage (Germinal vesicle break down) reported a 3 -fold increase in protein synthesis, after prior phosphorylation of eIF4E. At the MII (metaphase II) stage, inhibition of protein expression is observed, which may be due to blocking of eIF4E by its potential inhibitor, the 4E-BPI binding protein [7].

Correct termination of epigenetic processes and the acquisition of imprinting of the maternal genome are synonymous with the achievement of genomic maturity. However, knowledge of the transcriptional profile of oocytes and the mechanisms of their regulation is still insufficient.

\section{Nuclear maturation of oocytes}

Oogenesis is the process of female primary sex cells differentiation into mature gametes. Primary germ cells (gonocytes) are localised in the wall of the embryo yolk sac, and the allantois. Due to the ability to relocate, as a result of morphogenetic movements, they migrate along with the somatic cells of the intestinal mesentery, resulting in creation of primary, non-differentiated gonads. Migrating in the direction of gonads, primordial sex cells adopt irregular shapes, developing cytoplasmic extensions (up to 40 microns in length), pseudopodia and filopodia. These structures allow them to maintain constant contact during their movement. Primordial germ cells' (gonocytes') directed traffic towards gonads has chemotactic basis, with factors like TGF- $\beta 1$ (Transforming Growth Factor Beta) and extracellular matrix proteins - fibronectin and lamin, taking part in the process. Additionally, surface embryonic proteins (SSEA-1), surface adhesion proteins (NCAM) and cadherins, are responsible for maintaining the communication between groups of migratory primary cells [24]. After entering the cortex part of the gonad, primary sex cells transform into oogonia and initiate ovarian differentiation. Oogonia maintain high mitotic activity, which allows for a significant increase in their numbers. At the end of the fetal period, the last generation of oogonia after DNA autoreplication (4C) begins the meiotic division. They proceed through the stages of prophase of the first meiotic division from leptotene, through zygotene, pachytene and diplotene. In diplotene a halt in meiotic division occurs, with the resulting primary oocytes maintained at this stage until the ovulation. The oogenesis begins during fetal development, and lasts throughout the life of the female. However, only a small number of oocytes matures and undergos ovulation, whereas the remaining ovarian follicles undergo atresia [1].

The extended diplotene stage in vertebrates is called dictyotene. It is characterized by scattering of nuclear chromatin, previously condensed in the prophase. Blocking of the cell cycle in the dictyotene phase does not impede the process of oocyte differentiation. At this stage the oocytes are much larger than the oogonia and have more cellular organelles. It is also then, where we observe recombination of the genetic material of the parents. During this period intense cell growth occurs, which repeatedly increases its volume. Multiplication of the gamete mass is possible with the use necessary metabolites from the surrounding cumulus oophorus, together with proteins, lipids, and RNAs synthesized by the oocyte itself, necessary for proper fertilization and maintenance of the embryo during the first stages of life. The mechanism of stopping meiotic divisions is not fully explained. It is believed that it is regulated by oocyte maturations inhibitors secreted by follicular cells: OMI (oocyte maturations inhibitors) and cyclic AMP [9]. The completion of the first stage of nuclear maturation is resumed prior to each ovulation, resulting in the formation of secondary oocytes. The first meiotic division is asymmetric. As a result, the polar body which is subject to degeneration processes is separated from the oocyte. After completion of the divisions, the oocytes passes to metaphase II of the meiotic division, where it is again blocked. At this stage, the process of egg differentiation is complete. In addition, the meiosis results in a state in which haploid number of chromosomes is present in the oocyte during fertilization. During the sperm-oocyte reaction the metaphase block is broken. Therefore, the condition necessary for the completion of oocyte's meiosis, in all species, is the fertilization of the oocyte [1].

\section{Oocyte - somatic cells „cross-talk”}

The cytoplasmic maturity of the oocytes conditions the communication between the gametes and the surrounding follicular cells. The cells of the granular follicle layer move towards the oocyte, enclosing it with a single layer, forming the primary follicle. Growth of the oocyte occurs is also accompanied by proliferation of cells of the corona radiata, which is surrounding the oocyte to become the cumulus oophorus [13], [24], [25]. Two-way exchange of signals is performed by the projections of granulosa cells which reach through the zona pellucida to the plasma membrane of the ovum [26]-[29].

Normal oocyte growth during folliculogenesis and oogenesis, as well as gamete maturation, is associated with communication between the oocyte and cumulus cells (CCs). The molecular connection between these cells, called connexons, enables the 
transfer of small molecules between oocytes and CCs [30]. The corona radiata cells form a unique micro-environment for the proper development of the oocyte. These cells, by numerous gap-junctions, and by auto- and paracrine interactions communicate with each other, oocytes and granular cells of the follicle [31], [32]. Low molecular weight nutrients, nucleotides, amino acids and energy compounds, necessary for oocyte's growth phase, are also supplied through the gap-junctions. Interruption of those junctions inhibits the resumption of meiosis in oocyte, leading to chromatin de-condensation, transcriptional blockage, and lack of protein expression. It has been shown that gap-junction connections play a vital role in the achievement of nuclear and cytoplasmic maturation [33], [34].

Maturation of mammalian oocytes is associated with nuclear and cytoplasmic modifications, and these are tied to the proliferation and differentiation of cumulus oophorus cells. Regulation is achieved at the molecular level by the expression of genes associated with signal transduction pathways that are important for folliculogenesis and oogenesis. Many proteins, including BMP (bone morphogenetic protein), are involved in the regulation of oogenesis and the growth of the embryo [35].

Oocyte affects the expression of genes in the granulosa cells. KL factor (Kit ligand) secreted by the follicle cells regulates the oocyte's development [36]. This ligand binds to the c-kit receptor in the cell membrane of the oocyte, activating cell growth. Yoshinga et al. showed that the increase in expression of mRNA for KL in follicular cells cultured in vitro was influenced the presence of oocytes [37].

\section{Research perspectives}

Nowadays, when the growing demand for breeding of pigs, access to research material derived from these animals is significantly eased. Additionally, repeated estrous cycles and the number of ovulated oocytes in one cycle, allows for easily obtaining a large amount of those cells [6].

Studies on oocytes, mainly porcine, bring many possibilities for broadening the already considerable knowledge about them. The experiments usually relate to the whole ova and the respective cells co-existing with oocytes, for example: cells of the corona radiata [38]. Improving knowledge of cell culture would avoid disturbances in the epigenetic modification of genes, which are often present in in vitro cultures. In contrast, examining the exact mechanisms that influence the maturity of the ovum in vivo, could improve the results of in vitro maturation. It would be especially important for human reproduction and in vitro fertilization. The development of increasingly better methods of biological molecular analysis may allow to identify the expression of genes which have not yet been observed in an ovum. Recent studies in microarrays have allowed us to examine the expres- sion profiles of various genes, such as those involved in the formation of blood vessels and blood circulation in oocytes before and after maturation in vitro [39]. This gives hope for the future breakthroughs and broadens the overall knowledge about the mechanisms that govern the function of the ova.

\section{Acknowledgements}

Publication of this article was made possible by grant number UMO-2016/21/B/NZ9/03535 from Polish National Centre of Science

\section{Author details}

Marta Rybska, Department of Departemnt of Preclinical Sciences and Infectious Diseases, Poznań University of Life Sciences, Poznań, Poland, tel. +4861 8487104, e-mail: rybska@up.poznan.pl

\section{Conflicts of Interest}

The authors declare they have no conflict of interest

This paper does not contain any studies with human participants or animals performed by any of the authors

\section{References}

1. Bielański, A., T. M., Biotechnologia rozrodu zwierząt udomowionych. Wydawnictwo i drukarnia DRUKROL, 1997.

2. Bartel, H. and Państwowy Zakład Wydawnictw Lekarskich., Embriologia. Wydawnictwo Lekarskie PZWL, 2012.

3. Kotarska, K., "Ekspansja komórek ziarnistych wzgórka jajonośnego proces niezbędny do prawidłowego przebiegu owulacji i zapłodnienia," Postępy Biol. Komórki, vol. 36, no. 2, pp. 171-187, 2009.

4. Wang, Q. and Sun, Q. Y., "Evaluation of oocyte quality: Morphological, cellular and molecular predictors," Reprod. Fertil. Dev., vol. 19, no. 1, pp. 1-12, 2007.

5. Krisher, R. L., "The effect of oocyte quality on development.," J. Anim. Sci, vol. 82 E-Suppl, pp. E14-23, 2004.

6. Machatkova, P. Hulinska, J. Horakova, Z. Reckova, K. H., "Oestrous cycle stage influences the morphology and maturation of porcine oocytes in vitro," Orig. Pap. Vet. Med., vol. 53, no. 2, pp. 70-76, 2008.

7. Opiela J., K.-K. L., "Charakterystyka zdolnosci rozwojowej oocytow ssakow w aspekcie zaplodnienia i rozwoju zarodkowego. Cz. II. Regulacja dojrzalosci cytoplazmatycznej i genomowej," Biotechnologia, no. 2, pp. 151-162, 2005.

8. Patrizio, P., Fragouli, E., Bianchi, V., Borini, A., and Wells, D., "Molecular methods for selection of the ideal oocyte.," Reprod. Biomed. Online, vol. 15, no. 3, pp. 346-53, Sep. 2007

9. Polanski, Z., Molekularne podstawy rozrodczości człowieka i innych ssa ków : praca zbiorowa pod redakcja prof. Macieja Kurpisza. Termedia Wydawnictwa Medyczne, 2002.

10. Bukowska, D., Kempisty, B., Ciesiolka, S., Piotrowska, H., Antosik, P., Wozna, M., Porowski, S., Ociepa, E., Maryniak, H., Jaskowski, J. M., Bryja, A., N. M., "Molekularne aspekty procesu dojrzewania jądrowego i cytoplazmatycznego oocytów u świń," Med. Weter., vol. 69, no. 8, pp. 456-460, 2013

11. Budna, J. et al., "Expression of genes associated with BMP signaling pathway in porcine oocytes before and after IVM - a microarray approach," Reprod. Biol. Endocrinol., vol. 15, no. 1, p. 43, Dec. 2017.

12. Coticchio, G., Sereni, E., Serrao, L., Mazzone, S., Iadarola, I., and Borini, A. "What Criteria for the Definition of Oocyte Quality?," Ann. N. Y. Acad. Sci., vol. 1034, no. 1, pp. 132-144, Dec. 2004

13. Eppig, J. J., "Oocyte control of ovarian follicular development and function in mammals.", Reproduction, vol. 122, no. 6, pp. 829-38, Dec. 2001.

14. Jaskowski, J. M., K.B. and Wozna, M., Walczak, R.,Szczepanska, P., Dziuban, J., Jackowska, M., A.P., "Wybrane metody oceny kompetencji rozwojowej oraz selekcji oocytów i zarodków bydlęcych," Med. Weter., vol. 66, no. 11, p. s.740-744,bibliogr., 2010.

15. Opiela, J., Kątska-Książkiewicz, L., "Charakterystyka zdolności rozwojowej oocytów ssaków w aspekcie zapłodnienia i rozwoju zarodkowego. Cz. 1, Dojrzałość jądrowa i molekularne aspekty jej regulacji.," Biotechnologia, vol. 3, pp. 107-118, 2004

16. Wu, D., Cheung, Q. C.-K., Wen, L., and Li, J., "A Growth-Maturation System That Enhances the Meiotic and Developmental Competence of Porcine Oocytes Isolated from Small Follicles1," Biol. Reprod., vol. 75, no. 4, pp. 547-554, Oct. 2006. 
17. Moor, R. M., Dai, Y., Lee, C., and Fulka, J., "Oocyte maturation and embryonic failure.," Hum. Reprod. Update, vol. 4, no. 3, pp. 223-36.

18. Kempisty, B. et al., "Zona pellucida glycoprotein 3 (pZP3) and integrin $\beta 2$ (ITGB2) mRNA and protein expression in porcine oocytes after single and double exposure to brilliant cresyl blue test," Theriogenology, vol. 75, no. 8, pp. 1525-1535, May 2011.

19. Kempisty, B. et al., "Expression and cellular distribution of zona pellucida glycoproteins in canine oocytes before and after in vitro maturation," Zygote, vol. 23, no. 6, pp. 863-873, Dec. 2015.

20. Budna, J. et al., "Genes of cellular components of morphogenesis in porcine oocytes before and after IVM," Reproduction, vol. 154, no. 4, pp. 535 545, Oct. 2017

21. Tinkanen, H., Bläuer, M., Laippala, P., Tuohimaa, P., and Kujansuu, E. "Correlation between serum inhibin B and other indicators of the ovarian function.," Eur. J. Obstet. Gynecol. Reprod. Biol., vol. 94, no. 1, pp. 10913, Jan. 2001.

22. Hershey, J. W. B., "Translational Control in Mammalian Cells," Annu. Rev. Biochem., vol. 60, no. 1, pp. 717-755, Jun. 1991.

23. Shim, C., Lee, S. G., Song, W. K., Lee, C. S., Lee, K.-K., and Kim, K., "Laminin chain-specific gene expression during mouse oocyte maturation," Mol. Reprod. Dev., vol. 48, no. 2, pp. 185-193, Oct. 1997.

24. Diaz, F. J., Wigglesworth, K., and Eppig, J. J., "Oocytes determine cumulus cell lineage in mouse ovarian follicles," J. Cell Sci., vol. 120, no. 8, pp. 1330-1340, Mar. 2007

25. Gilchrist, R. B. et al., "Immunoneutralization of Growth Differentiation Factor 9 Reveals It Partially Accounts for Mouse Oocyte Mitogenic Activity1," Biol. Reprod., vol. 71, no. 3, pp. 732-739, Sep. 2004.

26. Albertini, D. F., Combelles, C. M., Benecchi, E., and Carabatsos, M. J., "Cellular basis for paracrine regulation of ovarian follicle development.," Reproduction, vol. 121, no. 5, pp. 647-53, May 2001

27. Matzuk, M. M., Burns, K. H., Viveiros, M. M., and Eppig, J. J., "Intercellular Communication in the Mammalian Ovary: Oocytes Carry the Conversation," Science (80-. )., vol. 296, no. 5576, pp. 2178-2180, Jun. 2002.

28. Matzuk, M. M. et al., "Transgenic models to study the roles of inhibins and activins in reproduction, oncogenesis, and development.," Recent Prog. Horm. Res., vol. 51, pp. 123-54-7, 1996.

29. Yamazaki, Y., Wakayama, T., and Yanagimachi, R., "Contribution of cumulus cells and serum to the maturation of oocyte cytoplasm as revealed by intracytoplasmic sperm injection (ICSI).," Zygote, vol. 9, no. 4, pp. 27782, Nov. 2001.

30. Kranc, W., Chachuła, A., Wojtanowicz-Markiewicz, K., S. C., Ociepa, E., Bukowska, D., Borys, S., Piotrowska, H., Bryja, A., Antosik, P., Brüssow, K., P., Nowicki, M., Kempisty, B., Bruska, M., "The Insight into Developmental Capacity of Mammalian Cocs and Cumulus-Granulosa Cells-Recent Studies and Perspectives," Austin J. Invit. Fertil., vol. 2, no. 3, pp. 1023 1027,2015

31. Guigon, C. J. and Magre, S., "Contribution of Germ Cells to the Differentiation and Maturation of the Ovary: Insights from Models of Germ Cell Depletion," Biol. Reprod., vol. 74, no. 3, pp. 450-458, Mar. 2006

32. Van Soom, A., Tanghe, S., De Pauw, I., Maes, D., and de Kruif, A., "Function of the cumulus oophorus before and during mammalian fertilization.," Reprod. Domest. Anim., vol. 37, no. 3, pp. 144-51, Jun. 2002.

33. Antosik, P. et al., "Assessment of transcript and protein levels contributing to cell cycle control and gap junction connections in morphologically variable groups of porcine cumulus-oocyte complexes," Vet. Med. (Praha)., vol. 55, no. 10, pp. 512-521, 2010.

34. Carabatsos, M. J., Sellitto, C., Goodenough, D. A., and Albertini, D. F., "Oocyte-Granulosa Cell Heterologous Gap Junctions Are Required for the Coordination of Nuclear and Cytoplasmic Meiotic Competence," Dev. Biol., vol. 226, no. 2, pp. 167-179, Oct. 2000.

35. Bukowska, D., Kempisty, B.,Zawierucha, P., Piotrowska,H., Antosik, P., Jackowska, M., Jaskowski, J. M., Bryja, A., N. M., "Wybrane aspekty zwiazane z zapłodnieniem in vitro u świń," Med. Weter., vol. 68, no. 12, pp. 717-721, 2012.

36. Robinson, L. L., Gaskell, T. L., Saunders, P. T., and Anderson, R. A., "Germ cell specific expression of c-kit in the human fetal gonad.," Mol. Hum. Reprod., vol. 7, no. 9, pp. 845-52, Sep. 2001.

37. Yoshinaga, K. et al., "Role of c-kit in mouse spermatogenesis: identification of spermatogonia as a specific site of c-kit expression and function.," Development, vol. 113, no. 2, pp. 689-99, Oct. 1991.

38. Kranc, W. et al., "Expression Profile of Genes Regulating Steroid Biosynthesis and Metabolism in Human Ovarian Granulosa Cells A Primary Culture Approach," Int. J. Mol. Sci., vol. 18, no. 12, p. 2673, Dec. 2017.

39. Nawrocki, M. J. et al., "The blood vessels development, morphogenesis and blood circulation are three ontologic groups highly up-regulated in porcine oocytes before in vitro maturation," Adv. Cell Biol., vol. 5, no. 2 pp. 135-142, Jan. 2017. 